\title{
Uzasadnione odstępstwa od zasady skargowości w kodeksie postępowania karnego?
}

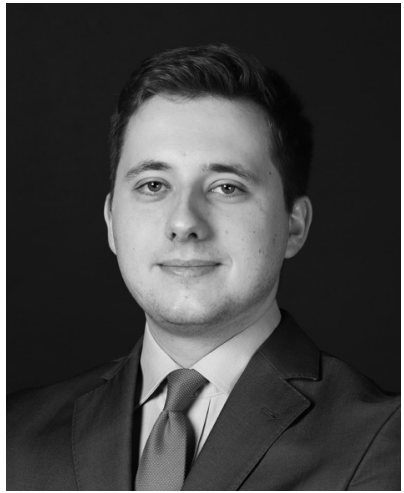

\section{Artur Karol Kowalczyk}

Doktorant w Katedrze Postępowania Karnego na Wydziale Prawa, Administracji i Ekonomii Uniwersytetu Wrocławskiego, absolwent aplikacji sędziowskiej w Krajowej Szkole Sadownictwa i Prokuratury. Jego zainteresowania badawcze dotycza m.in. naczelnych zasad procesowych i rozwiązań modelowych procesu karnego. $\triangle$ artur.kowalczyk@uwr.edu.pl https://orcid.org/oooo-0oo2-6777-4735

\section{A Justified Departure from the Principle of Accusatorial Procedure in the Code of Criminal Procedure?}

\begin{abstract}
Principle of accusatorial procedure states that criminal proceedings should be conducted only upon the request of a party and thus, the court cannot take the initiative. By the Act of 11 March 2016 the courts' right to demand supplementing preparatory proceeding during preliminary verification of indictment has been brought back to the criminal procedure. The possibility of adjourning or deferring the trial in order to demand additional evidence has also been restored. The aim of the paper is to consider how these court powers affect the principle of accusatorial procedure and to answer the question whether departure from this principle is justified, for example, by the need to comply with other principles of criminal proceedings.
\end{abstract}

\footnotetext{
Słowa kluczowe: zasada skargowości, kolizja zasad, postępowanie przejściowe, kontrola oskarżenia, inicjatywa dowodowa sądu

Key words: criminal proceedings, accusatorial procedure, criminal justice system, fair trial

https://doi.org/10.32082/fp.v4i54.242
}

\section{Uwagi wstępne}

Zasada skargowości, mająca swoje normatywne zakotwiczenie $\mathrm{w}$ art. $14 \$ 1$ k.p.k., jest naczelną zasadą procesu karnego o pierwszorzędnym znaczeniu. Można zaryzykować twierdzenie, że stanowi ona jedną z najbardziej doniosłych zasad procesu, o czym świadczy fakt, iż skargowość postrzega się jako kryterium wyróżnienia trzech historycznych form rozwoju procesu karnego, do których w polskim piśmiennictwie tradycyjnie zaliczane są: forma skargowa, inkwizycyjna oraz mieszana, stanowiąca kompilację dwóch poprzednich ${ }^{1}$. W przebiegu

1 S. Śliwiński, Polski proces karny przed sądem powszechnym. Zasady ogólne, Warszawa 1948, s. 12 i n.; C. Kulesza, 
historycznego rozwoju zasada skargowości ukształtowała się zatem wcześniej niż alternatywna zasada działania z urzędu i stanowiła charakterystyczną cechę procesu karnego w czasach antycznych, zwłaszcza w starożytnym procesie rzymskim, co znalazło swój wyraz w paremii nemo iudex sine actore, a w doktrynie niemieckiej zawiera się w popularnej formule wo kein Kläger, da kein Richter ${ }^{2}$. Zasada skargowości wespół z zasadą kontradyktoryjności ma więc decydujące znaczenie z punktu widzenia klasyfikacji systemów prawa karnego procesowego ze względu na formę $e^{3}$ Na stopień realizacji zasady skargowości $\mathrm{w}$ procesie karnym istotny wpływ miała nowelizacja Kodeksu postępowania karnego z 2016 r. ${ }^{4}$, która - jak się często wskazuje - stanowiła radykalny odwrót od reformy procedury karnej dokonanej nowelizacjami z lat 2013-2015 . Tak zwaną nowelą marcową przywrócono występujące w k.p.k. do dnia 30 czerwca 2015 r. instytucje zwrotu sprawy do uzupełnienia braków postępowania przygotowawczego (art. 344a i 344b k.p.k.) oraz odroczenia lub przerwy w rozprawie celem przedstawienia dowodów przez oskarżyciela (art. 396a k.p.k.). Zadaniem niniejszego opracowania jest określenie związku tych zmian legislacyjnych ze stopniem realizacji zasady skargowości w procesie karnym oraz rozważenie, czy za przywróceniem wymienionych instytucji stoją dostatecznie silne racje, zwłaszcza w kontekście gwarancyjnej funkcji omawianej zasady.

Zasada skargowości (w:) P. Wiliński (red.), System Prawa Karnego Procesowego, t. 3: Zasady procesu karnego, cz. 1, Warszawa 2014, s. 550.

2 S. Waltoś, P. Hofmański, Proces karny. Zarys systemu, Warszawa 2016, s. 272.

3 S. Stachowiak, Funkcje zasady skargowości w polskim procesie karnym, Poznań 1975, s. 19-20.

4 Ustawa z dnia 11 marca 2016 r. o zmianie ustawy - Kodeks postępowania karnego oraz niektórych innych ustaw, Dz.U. 2016, poz. 437 (dalej: nowela marcowa), która weszła w życie w dniu 15 kwietnia $2016 \mathrm{r}$.

5 Mowa tu o Ustawie z dnia 27 września 2013 r. o zmianie ustawy - Kodeks postępowania karnego oraz niektórych innych ustaw, Dz.U. 2013, poz. 1247 ze zm. (dalej: nowela wrześniowa) i Ustawie z dnia 20 lutego 2015 r. o zmianie ustawy - Kodeks karny oraz niektórych innych ustaw, Dz.U. 2015, poz. 396.

\section{Pojęcie, funkcje i optymalizacyjny charakter zasady skargowości}

Wokół definiowania zasady skargowości narosło wiele sporów, wynikających z odnoszenia jej albo wyłącznie do skargi inicjującej postępowanie przed sądem I instancji, albo do wszelkich pochodzących od stron oświadczeń woli o charakterze postulatywnym, które określa się zbiorczym mianem skarg. Według Mariana Cieślaka w procesie karnym mamy bowiem do czynienia z trzema ich rodzajami. Pierwszym jest skarga zasadnicza, tj. akt oskarżenia, ewentualnie jego surogaty, takie jak np. wniosek o warunkowe umorzenie postępowania karnego, drugą grupę stanowią skargi etapowe, przesuwające proces do kolejnego etapu, jak np. apelacja lub wniosek o wznowienie postępowania, do trzeciej zaś zaliczyć trzeba skargi incydentalne prowadzące do rozpatrzenia kwestii wpadkowych - będzie to np. zażalenie na postanowienie o zastosowaniu tymczasowego aresztowania ${ }^{6}$.

Przechodząc do kwestii zakresu pojęciowego zasady skargowości, wyróżnić można zarówno jej szerokie, jak i wąskie ujęcie, a w ramach tego ostatniego - wąskie i najwęższe ${ }^{7}$. Zgodnie z zasadą skargowości w ujęciu najwęższym ,jurysdykcyjne (sądowe) stadium procesu toczy się wyłącznie w następstwie wniesienia skargi przez uprawnionego oskarżyciela"”. Odwrotną stroną medalu będzie tu więc nakaz wszczęcia postępowania z urzędu, co było cechą charakterystyczną feudalnego procesu inkwizycyjnego, stąd też zasada przeciwna nazywana jest zasadą inkwizycyjności. Skargowość sensu strictissimo tyczy się więc tylko i wyłącznie sposobu rozpoczęcia procesu, a zatem nie uwzględnia skarg innych niż zasadnicze. W ujęciu nieco tylko szerszym, choć nadal kwalifikującym się jako wąskie, „sąd nie może wszcząć postępowania z własnej inicjatywy, a jedynie na żądanie uprawnionego oskarżyciela, przy czym jeśli zostanie ono złożone, sąd jest zobowiązany

6 M. Cieślak, Polska procedura karna. Podstawowe założenia teoretyczne, Warszawa 1974, s. 259-260.

7 E. Kruk, Zasada skargowości w polskim procesie karnym, „Studia Iurudica Lublinensia” 2016, t. 25, s. 213-214; S. Waltoś, P. Hofmański, Proces karny..., dz. cyt., s. 272-273.

8 Tak R. Kmiecik, E. Skrętowicz, Proces karny. Część ogólna, Warszawa 2009, s. 71. 
do wszczęcia postępowania"`. Zasada skargowości sensu stricto wciąż miałaby się odnosić jedynie do momentu wszczęcia fazy sądowej postępowania karnego. Ujęcie to, w porównaniu z poprzednim, zostaje więc wzbogacone o element konieczności rozpoznania skargi przez sąd. Nadal jednak skargowość odnosi się wyłącznie do skargi zasadniczej. Wydaje się, że najbardziej trafne jest ujęcie szerokie, zgodnie z któ- że w takim ujęciu nie ma mowy o obowiązku wszczęcia postępowania przez sąd. Trafnie bowiem wskazał Andrzej Murzynowski, że ten element jest już konsekwencją zasady legalizmu ${ }^{13}$. Wydaje się, że funkcja obligacyjna skargi, a więc i zasady skargowości polega nie tyle na konieczności jej rozpoznania przez sąd, co na związaniu sądu (co do zasady) granicami skargi.

Choć zasada skargowości została prawnie zde-

\section{Zasada skargowości dotyczy nie tylko wszczęcia postępowania przed sądem, ale i jego dalszego prowadzenia.}

rym zasada skargowości dotyczy nie tylko wszczęcia postępowania przed sądem, ale i jego dalszego prowadzenia. Według M. Cieślaka zasada skargowości (nie bez przyczyny nazywana przez tego autora również zasadą działania na wniosek) stanowi dyrektywę "prowadzenia postępowania na wniosek podmiotu bezpośrednio zainteresowanego w tym postępowaniu i jego wyniku"10. Ujęcie to oprócz skargi zasadniczej obejmuje również skargi etapowe oraz incydentalne.

W dalszych rozważaniach stosowane będzie szerokie ujęcie zasady skargowości. Nie tylko dlatego, że do jego zaaprobowania skłania treść art. $14 \$ 1$ k.p.k. ${ }^{11}$, skoro mowa w nim o innym uprawnionym podmiocie (a nie tylko o oskarżycielu), lecz również z tego powodu, że motywy stojące za zasadą skargowości w równym stopniu dotyczą innych sytuacji, w których sąd nie działa $\mathrm{z}$ własnej inicjatywy, lecz dopiero na skutek postulatywnego oświadczenia woli zainteresowanego. Należy zatem przyjąć, że zasada skargowości stanowi dyrektywę prowadzenia postępowania przez sąd i rozstrzygania o jego przedmiocie na wniosek uprawnionego podmiotu ${ }^{12}$. Jednocześnie należy zwrócić uwagę,

9 S. Stachowiak, Funkcje zasady skargowości..., dz. cyt., s. 15.

10 M. Cieślak, Polska procedura..., dz. cyt., s. 258.

11 E. Kruk, Zasada skargowości..., dz. cyt., s. 213-214.

12 Por. C. Kulesza, Zasada skargowości (w:) P. Wiliński (red.), System..., dz. cyt., s. 558. Podobnie J. Tylman (w:) T. Grze- finiowana w art. $14 \$ 1$ k.p.k., to jednocześnie nie posiada umocowania w Konstytucji RP i z reguły jest wymieniana jako typowy przykład pozakonstytucyjnej naczelnej zasady procesowej. Także z art. 6 EKPCz można tę zasadę wyinterpretować jedynie pośrednio, przyjmując, że w wykreowanym na bazie tego przepisu standardzie rzetelnego procesu karnego mieści się powiązana z nią zasada kontradyktoryjności (o związku tych dwóch zasad będzie jeszcze mowa) ${ }^{14}$. Mimo niewyrażenia zasady wprost w ponadustawowych aktach prawnych regulujących sferę praw i wolności człowieka, bezsporny jest jej gwarancyjny charakter. Wskazuje się między innymi, że w historii zasada ta łączyła się z reguły z bardziej demokratycznymi, liberalnymi konstrukcjami procesu karnego ${ }^{15}$. Bez wątpienia skargowość sprzyja bezstronności sądu, który może zachować odpowiedni dystans do sprawy, z pewnością większy niż w przypadku, gdyby samodzielnie wszczynał postępowanie, co determinowałoby chęć wykazania, iż decyzja ta była słuszna. W takiej

gorczyk, J. Tylman, Polskie postępowanie karne, Warszawa 2014, s. 105.

13 A. Murzynowski, Istota i zasady procesu karnego, Warszawa 1984, s. 156.

14 C. Kulesza, Zasada skargowości (w:) P. Wiliński (red.), System..., dz. cyt., s. 599-600.

15 A. Murzynowski, Istota i zasady..., dz. cyt., s. 156. 
sytuacji ewentualne uwolnienie oskarżonego od odpowiedzialności byłoby w pewnym sensie niepowodzeniem sądu. Obowiązywanie zasady skargowości skutkuje rozdziałem trzech funkcji procesowych: oskarżania, obrony i orzekania. Taka trójpodmiotowa struktura procesu w sposób radykalny odróżnia go od procesu inkwizycyjnego, w ramach którego dochodzi do kumulacji ról procesowych przez niemal wszechwładny organ prowadzący postępowanie przy jednoczesnej marginalizacji stron postępowania. Od dawna podnosi się, że łączenie sprzecznych ze sobą funkcji czyni wątpliwą możliwość zachowania należytego obiektywizmu. Dzięki separacji funkcji ścigania i oskarżania od rozstrzygania oskarżony może realnie oczekiwać, że sąd rozpoznający jego sprawę zachowa maksymalny obiektywizm ${ }^{16}$.

Wskazano już, że jakkolwiek zasada skargowości wykazuje bliskie związki z zasadą kontradyktoryjności, to jednak zasad tych nie należy utożsamiać ${ }^{17}$. W przypadku ujęcia wąskiego zasady skargowości jej odrębność od zasady kontradyktoryjności jest nawet bardziej widoczna, bowiem wówczas zasada kontradyktoryjności niejako przejmuje rolę zasady skargowości na dalszym etapie postępowania. Zdaniem Beaty T. Bieńkowskiej „kontradyktoryjność stanowi swoistego rodzaju kontynuację skargowości"18. Także jednak w przypadku szerokiego ujęcia zasady skargowości nie należy traktować obu zasad synonimicznie. Zasada skargowości wyznacza cały układ procesowy, przede wszystkim determinuje występowanie stron oraz sekwencję realizowania ich procesowych ról.

16 Dostrzegano to już w doktrynie okresu międzywojennego. S. Glaser pisał, że separacja ról procesowych jest pożądana z uwagi na interes wymiaru sprawiedliwości oraz ze względu na stanowisko procesowe oskarżonego, które może dzięki temu mieć pewność, że przestrzegane będą jego uprawnienia procesowe, a sąd nie będzie uprzedzony do sprawy i będzie mógł zająć stanowisko absolutnie obiektywne. Zob. tegoż, Wstęp do nauki procesu karnego, Warszawa 1928, s. 59-61.

17 C. Kulesza, Zasada skargowości (w:) P. Wiliński (red.), System..., s. 553; S. Stachowiak, Funkcje zasady skargowości..., s. $19-20$.

18 B.T. Bieńkowska, Wybrane aspekty wzajemnej relacji zasad skargowości i kontradyktoryjności oraz ich wpływu na określenie formy procesu $i$ kształtu sporu stron przed sądem, „Przegląd Sądowy” 1997, nr 6, s. 50.
Wiąże się to ściśle z rozkładem ciężaru dowodu, stanowiącym warunek konieczny realizacji kontradyktoryjności. To spoczywający na oskarżycielu onus probandi nakazuje mu postawienie twierdzenia (zarzutu), co z kolei inicjuje zachowanie podmiotu, który broni się przed oskarżeniem ${ }^{19}$. W ten sposób powstaje spór, w którego toku strony usiłują wykazać słuszność swoich twierdzeń i wówczas dopiero powstaje miejsce dla zasady kontradyktoryjności, która reguluje już sam sposób prowadzenia sporu między tymi stronami. Można więc powiedzieć, że skargowość jest jednym z warunków kontradyktoryjności albo też że niejako ową kontradyktoryjność poprzedza. Warto zwrócić uwagę, że skargowość sama w sobie nie przesądza o równości broni stron ani też o bezstronności sądu, a przecież te elementy także warunkują proces kontradyktoryjny ${ }^{20}$. Wprawdzie teoretycznie jest możliwe istnienie procesu skargowego, który zupełnie nie opiera się na zasadzie kontradyktoryjności, jednak w rzeczywistości obie te zasady występują łącznie, stanowiąc dwie strony tego samego medalu. Przyjmuje się, że obie przesądzają o całym modelu procesu określanego mianem kontradyktoryjno-skargowego ${ }^{21}$.

W tym miejscu trzeba wyjaśnić, jakie zadanie w procesie karnym pełni zasada skargowości. Stanisław Stachowiak wyróżnia dwie zasadnicze funkcje: po pierwsze funkcję impulsu procesowego, po drugie zaś funkcję obowiązku procesowego. Funkcja impulsu procesowego przejawia się tym, że skarga uprawnionego oskarżyciela stanowi siłę napędową procesu, natomiast funkcja obowiązku procesowego polega na konieczności rozpoznania sprawy przez sąd w granicach zakreślonych skargą ${ }^{22}$. Oprócz dwóch wskazanych funkcji współcześnie wyróżnia się dodatkowo funkcję konstrukcyjną, związaną z ukształtowaniem

19 P. Wiliński, Materialny ciężar dowodu winy oskarżonego przyczynek do rozważań (w:) P. Kardas, T. Sroka, W. Wróbel (red.), Państwo prawa i prawo karne. Księga Jubileuszowa Profesora Andrzeja Zolla, t. 2, Warszawa 2012, s. 1846-1848.

20 B.T. Bieńkowska, Wybrane aspekty..., dz. cyt., s. 49.

21 Por. A. Murzynowski, Znaczenie zasad skargowości i kontradyktoryjności $w$ działalności sądów w świetle przepisów nowego kodeksu postępowania karnego (w:) T. Nowak (red.), Nowe prawo karne procesowe. Zagadnienia wybrane. Ksiega ku czci Profesora Wiesława Daszkiewicza, Poznań 1999.

22 S. Stachowiak, Funkcje zasady skargowości..., dz. cyt., s. 24-27. 
trójpodmiotowej struktury procesu, a także - zwłaszcza w nowszej literaturze - funkcję gwarancyjną ${ }^{23}$. Ta ostatnia jest ściśle powiązana z funkcją obowiązku procesowego (tzw. funkcją względnie obligującą). Funkcja gwarancyjna wynika stąd, że skarga zakreśla granice przedmiotowe i podmiotowe, którymi sąd jest związany. Dla oskarżonego oznacza to więc stan pewności, czego dotyczyć będzie postępowanie, a w konsekwencji daje mu to możliwość właściwego przygotowania obrony. W dalszej części w głównej mierze analizowany będzie stopień realizacji tej właśnie funkcji zasady skargowości w kontekście wprowadzenia (a właściwie przywrócenia) instytucji uregulowanych w art. 344a i art. 396a k.p.k. wania (art. $542 \$ 1$ k.p.k.), wszczęciu postępowania w przedmiocie wydania wyroku łącznego (art. 570 k.p.k.) czy podjęcia postępowania warunkowo umorzonego (art. 549 k.p.k.). Przede wszystkim jednak, nawet w przypadku skargi zasadniczej, czyli aktu oskarżenia, obligująca moc nie ma charakteru absolutnego. Przyjmuje się, że sąd jest związany jedynie granicami zdarzenia historycznego opisanego w skardze, może natomiast zmodyfikować opis zdarzenia i zmienić kwalifikację prawną. Nie jest natomiast dopuszczalne wyjście poza granice skargi poprzez rozpoznanie sprawy innej osoby, co do której w toku postepowania wyłoniło się podejrzenie popełnienia przestępstwa albo też rozpoznawanie innego czynu

\section{Istnienie licznych odstępstw od zasady} skargowości, powszechnie uważanej za dominującą, dowodzi słuszności tezy o optymalizacyjnym charakterze zasad prawa.

Zakres odstępstw od omawianej zasady na rzecz zasady inkwizycyjności i zasady działania z urzędu pozostaje bardzo szeroki ${ }^{24}$. Wszak postępowanie przygotowawcze wszczynane jest $\mathrm{z}$ urzędu i opiera się na zasadzie inkwizycyjnej, a nadto w postępowaniu sądowym istnieje szereg wyjątków uprawniających sąd do działania z urzędu. Warto zauważyć, że tylko postępowanie sądowe dotyczące kwestii głównej można wszcząć wyłącznie na żądanie uprawnionego oskarżyciela. W przypadku postępowań incydentalnych i następczych ustawa przewiduje liczne wyjątki od zasady skargowości, by wymienić tu np. możliwość działania z urzędu przy wznowieniu postępo-

23 Zob. K. Dudka, H. Paluszkiewicz, Postępowanie karne, Warszawa 2016, s. 186-187, gdzie wymienia się aż sześć różnych funkcji pełnionych przez skargę.

24 O możliwości przeciwstawiania zasady skargowości różnym zasadom procesowym zob. R. Kmiecik, Oskarżyciel posiłkowy w procesie karnym, Warszawa 1977, s. 23-24. rozumianego jako inne zdarzenie historyczne ${ }^{25}$. Mimo licznych ograniczeń, najprawdopodobniej z uwagi na decydujące znaczenie fazy jurysdykcyjnej w postępowaniu karnym, to zasada skargowości jest w procesie karnym uznawana za dominującą, a zasada działania z urzędu stanowi od niej wyjątek ${ }^{26}$.

Istnienie licznych odstępstw od zasady skargowości, powszechnie uważanej za dominującą, dowodzi słuszności tezy o optymalizacyjnym charakterze zasad prawa, sformułowanej przez Ronalda Dworkina, a zaadaptowanej na potrzeby nauki prawa kontynentalnego przez Roberta Alexy'ego ${ }^{27}$. W ujęciu

25 P. Hofmański, S. Waltoś, Proces karny..., dz. cyt., s. 275-276. 26 Tak np. J. Tylman (w:) T. Grzegorczyk, J. Tylman, Polskie postępowanie..., dz. cyt., s. 106.

27 Zob. R. Alexy, Teoria praw podstawowych, tłum. B. Kwiatkowska, J. Zajadło, Warszawa 2010; teorię R. Alexy’ego omawiają m.in. T. Gizbert-Studnicki, Zasady i reguły prawne, „Państwo i Prawo" 1988, z. 3; M. Korycka, Teoria zasad prawnych 
R. Dworkina i R. Alexy'ego optymalizacyjny charakter zasad (principles) przejawia się tym, że mogą one być realizowane w pewnym, większym lub mniejszym stopniu, co odróżnia je od reguł (rules), które mogą być spełnione w całości albo w ogóle ${ }^{28}$. Zasady prawa nie wyznaczają zachowania w sposób definitywny (nie są konkluzywne), a jedynie wskazują pożądany kierunek działania, który może być racjonalizowany, gdy zachodzi taka konieczność, wywołana kolizją z innymi zasadami. Cechę tę, nadającą dużą elastyczność, odnieść można do zdecydowanej większości naczelnych zasad procesu karnego, wśród których jedynie zasady domniemania niewinności i in dubio pro reo stanowią reguły w rozumieniu Dworkina i Alexy'ego. Przyjęło się jednak uznawać je za zasady procesowe, albowiem na gruncie polskim przede wszystkim doniosłość społeczna i ideologiczna zasad stanowi ich kryterium wyodrębnienia, co skłania niektórych teoretyków do twierdzenia o nieadekwatności koncepcji Alexy'ego do polskiego systemu prawa ${ }^{29}$.

\section{Nowe wcielenie dawnych instytucji procesowych}

Nowelą marcową wprowadzono do ustawy karnej procesowej istotne zmiany wpływające na stopień realizacji zasady skargowości w jurysdykcyjnej fazie postępowania. Wymienić tu należy przede wszystkim nowe art. 344a i art. 344b k.p.k. oraz art. 396a k.p.k. Przepisy te stanowią dosłowne powtórzenie przepisów uchylonych nowelą wrześniową umiejscowionych wcześniej odpowiednio w art. 345 i art. 346 oraz art. 397 k.p.k. Gwoli ścisłości zauważyć należy, że nowela marcowa utrzymała dotychczasowy kształt przepisu art. $14 \$ 2$ k.p.k. nadany mu nowelą wrześniową, która niewiążące sądu odstąpienie oskarżyciela od oskarżenia zastąpiła możliwością cofnięcia aktu oskarżenia, powodującą konieczność umorzenia postępowania na podstawie

Roberta Alexy'ego, „Archiwum Filozofii Prawa i Filozofii Społecznej" 2010, nr 1; M. Araszkiewicz, T. Gizbert-Studnicki, Teoria praw podstawowych Roberta Alexy'ego, „Przegląd Sejmowy" 2011, nr 3.

28 Por. O. Bogucki, M. Zieliński, Zasady prawa z perspektywy ogólnej teorii prawa (w:) P. Wiliński (red.) System..., dz. cyt., s. 62 .

29 O. Bogucki, M. Zieliński, Zasady prawa..., dz. cyt., s. 60-73. art. $17 \$ 1$ pkt 9 k.p.k. W ten sposób z procesu karnego wyeliminowano, już raczej definitywnie, radykalny wyłom od zasady skargowości, polegający na możliwości kontynuowania postępowania przed sądem pomimo braku oskarżyciela popierającego skargę. Jednocześnie jednak przywrócono dawne brzmienie art. 167 k.p.k., umożliwiając sądowi - bez żadnych ograniczeń - przeprowadzanie dowodów z urzędu, a także art. $366 \$ 1$ k.p.k., w myśl którego przewodniczący ma obowiązek nie tylko kierowania rozprawą i czuwania nad jej prawidłowym przebiegiem, ale również dopilnowania, by zostały wyjaśnione wszystkie istotne okoliczności sprawy. Obie te zmiany stanowią przejaw zerwania $\mathrm{z}$ takim układem ról procesowych w ramach trójpodmiotowego procesu karnego, który został nadany tzw. wielką nowelą z 2013 r., a pośrednio wpływają również na zakres realizacji zasady skargowości.

Celem niniejszego szkicu jest skonfrontowanie z zasadą skargowości wyłącznie art. 344a oraz art. 396a k.p.k. Uwagi na temat przesłanek uregulowanych w nich instytucji oraz trybu ich stosowania zostaną ograniczone do absolutnego minimum, tym bardziej że z uwagi na identyczne brzmienie powołanych przepisów oraz ich „poprzedników” z art. 345 i art. 346 k.p.k. wypowiedzi doktryny na temat stanu prawnego obowiązującego przed dniem 1 lipca 2015 r. pozostają w pełni aktualne i można je odnosić wprost do reaktywowanej przez ustawodawcę instytucji. Artykuł 344a $\$ 1$ k.p.k. formułuje dwie przesłanki, których łączne spełnienie zobowiązuje sąd na etapie kontroli formalnej i merytorycznej aktu oskarżenia w toku postępowania przejściowego do zwrotu sprawy prokuratorowi w celu uzupełnienia śledztwa lub dochodzenia. Są one następujące: po pierwsze akta sprawy wskazują na istotne braki postępowania przygotowawczego, zwłaszcza na potrzebę poszukiwania dowodów, po drugie dokonanie niezbędnych czynności przez sąd powodowałoby znaczne trudności ${ }^{30}$. Każda $\mathrm{z}$ tych dwóch przesłanek scharakteryzowana jest znamie-

30 S. Stachowiak, Czynności sądu w fazie poprzedzającej rozprawe główną w ujęciu nowego kodeksu postępowania karnego (w:) Nowa kodyfikacja karna. Kodeks postępowania karnego. Krótkie komentarze, z. 3, Warszawa 1997, s. 30. 
niem ocennym (istotne braki, znaczne trudności) ${ }^{31}$, co jak łatwo się domyślić, generuje poważne problemy interpretacyjne. Na tle dawnego art. 345 k.p.k. powstało obszerne orzecznictwo. Nie miejsce tu na podawanie konkretnych przykładów braków, które w ocenie Sądu Najwyższego i sądów powszechnych uzasadniają zwrot sprawy ${ }^{32}$. Dość powiedzieć, że poprzez „istotne braki” rozumie się nie tylko braki dowodowe (na co wskazuje użycie przez ustawodawcę słowa „Zwłaszcza”), ale również inne wady postępowania utrudniające rzetelne rozpoznanie sprawy przez sąd, natomiast „znaczne trudności” określa się jako sytuacje, gdy konieczność uzupełnienia postępowania naruszałaby zasadę koncentracji rozprawy głównej, ciągłości i szybkości postępowania sądowego $^{33}$. Ogólnie rzecz biorąc, wyróżnić można dwa rodzaje braków: są to braki dowodowe wynikające z pominięcia lub nieprawidłowego przeprowadzenia dowodu albo uchybienia proceduralne utrudniające lub uniemożliwiające wydanie rozstrzygnięcia, w tym również takie, które ograniczają prawo do obrony ${ }^{34}$.

W art. 344b k.p.k. wymienia się, w jaki sposób może postąpić oskarżyciel publiczny po uzupełnieniu śledztwa lub dochodzenia. Istnieje więc możliwość podtrzymania dotychczasowego aktu oskarżenia, złożenia nowego aktu oskarżenia, złożenia wniosku o warunkowe umorzenie postępowania lub umorzenia postępowania. Wskazuje się również, że choć nie wyrażono tego wprost, możliwe jest jeszcze zawieszenie postępowania karnego ${ }^{35}$. W przeszłości $\mathrm{w}$ doktrynie spierano się o skutki zwrotu sprawy do

31 P. Lewczyk, Procesowa kontrola postępowania przygotowawczego, „Prokuratura i Prawo” 2006, nr 9, s. 91.

32 Liczne przykłady omawia szczegółowo T. Razowski, Formalna i merytoryczna kontrola oskarżenia $w$ polskim procesie karnym, Kraków 2005, s. 189-211. Zob. również M. Latos, Istotne braki postępowania przygotowawczego w judykaturze, „Prokuratura i Prawo” 2010, nr 6.

33 P. Hofmański, E. Sadzik, K. Zgryzek, Kodeks postępowania karnego. Komentarz do artykułów 297-467, t. 2, Warszawa 2011, s. 263-264.

34 M. Latos, Istotne braki..., dz. cyt., s. 138-139.

35 S. Stachowiak, Decyzje procesowe podejmowane po uzupetnieniu śledztwa lub dochodzenia w polskim postępowaniu karnym (w:) J. Skorupka (red.), Rzetelny proces karny. Ksiegga jubileuszowa Profesor Zofii Świdy, Warszawa 2009, s. 317-318. uzupełnienia braków dla stanu zawisłości sprawy przed sądem. Ostatecznie zwyciężył pogląd, że zwrot ten powoduje przesunięcie sprawy z powrotem do postępowania przygotowawczego i odzyskanie przez organ prowadzący postępowanie przygotowawcze statusu dominus litis. Ustaje zatem stan zawisłości przed sądem, a sprawa wraca do postępowania przygotowawczego; innymi słowy - unicestwiona zostaje faza sądowa postępowania ${ }^{36}$. Stanowi to o wyjątkowym charakterze omawianych przepisów, których nie wolno interpretować rozszerzająco ${ }^{37}$. Podkreślenia wymaga, że zakres uzupełnienia braków może być szerszy od wskazanego przez sąd. Organ prowadzący postępowanie przygotowawcze nie jest zatem bezwzględnie związany postanowieniem o zwrocie. S. Stachowiak jeszcze na gruncie k.p.k. z 1969 r. posłużył się następującą metaforą: sternikowi (prokuratorowi) został co prawda wyznaczony kurs (kierunek uzupełnienia postępowania przygotowawczego), pozostawiono mu jednak swobodę manewru w postaci możliwości dokonywania korekty kursu, a co najważniejsze, nie określono mu „portu przeznaczenia, celu podróży” (prokurator ma swobodę w zakresie podjęcia decyzji kończącej postępowania przygotowawcze po jego uzupełnieniu) ${ }^{38}$.

Temu samemu celowi, lecz już na innym, bardziej zaawansowanym etapie postępowania karnego służy zlecenie przedstawienia dowodów przez oskarżyciela w trybie art. 396a k.p.k. ${ }^{39}$ Przesłankami przerwy lub odroczenia rozprawy w tym celu są: po pierwsze ujawnienie się w toku rozprawy istotnych braków postępowania przygotowawczego, po drugie niemożność wydania rozstrzygnięcia przez sąd w rozsądnym terminie w przypadku samodzielnego uzupełnienia i po trzecie niemożność usunięcia tych braków w sposób

36 J. Bafia, Zwrot sprawy przez sąd do uzupetnienia śledztwa lub dochodzenia, Warszawa 1961, s. 85.

37 S. Cora, Zwrot sprawy do uzupetnienia braków postępowania przygotowawczego w polskim procesie karnym, Warszawa 1987, s. 30. Tak też T. Razowski, Formalna i merytoryczna... s. 188 .

38 S. Stachowiak, Funkcje zasady skargowości..., dz. cyt., s. 127.

39 S. Stachowiak, Uzupetnienie postepowania przygotowawczego przez prokuratora (art. $397 \$ 1$ k.p.k.), „Prokuratura i Prawo” 2003, nr 10; R.A. Stefański, Czynności dowodowe prokuratora zlecone przez są, „Prokuratura i Prawo” 2003, nr 5. 
przewidziany w art. 396 k.p.k. Choć przesłanki pozostają dosyć podobne jak w przypadku art. 344a k.p.k., zupełnie inne są jednak skutki zastosowania art. 396a k.p.k., który nie powoduje ustania stanu litis pendens. W tym kontekście zwrócić należy uwagę na niejasną rolę prokuratora, który, nie będąc już organem, lecz na rozprawie, zamiast poruszać się w granicach skargi, sąd przerywa bądź też odracza rozprawę, wyznaczając oskarżycielowi termin do przedstawienia określonych dowodów. A jednak nad stwierdzeniem, że przywrócenie z dniem 15 kwietnia 2016 r. tych dwóch instytucji (powstrzymując się na razie z jakąkolwiek oceną

\section{Wezwanie do przedstawienia dowodów, podobnie jak zwrot sprawy do uzupełnienia braków czynią sąd inicjatorem czynności o charakterze dowodowym.}

jedynie stroną postępowania jako oskarżyciel, nabywa w ten sposób władcze kompetencje w celu efektywnego prowadzenia postępowania dowodowego. Nadto omawianej regulacji zarzucić można przeciwskuteczność, jako że w rzeczywistości trudno wyobrazić sobie czynności, których nie można by dokonać w toku rozprawy, a zakreślenie terminu do przedstawienia dowodów może wydłużyć proces w większym jeszcze stopniu niż przeprowadzenie odpowiednich czynności na rozprawie. Wreszcie wezwanie do przedstawienia dowodów, podobnie jak zwrot sprawy do uzupełnienia braków czynią sąd inicjatorem czynności o charakterze dowodowym, co nie zasługuje na aprobatę z uwagi na ryzyko utraty niezbędnego dystansu do sprawy, zarówno w aspekcie wewnętrznym, tj. autentycznego przekonania sędziego, jak i czysto obiektywnym, czyli jego odbioru w oczach uczestników procesu, a zwłaszcza oskarżonego.

\section{Zwrot sprawy do uzupetnienia braków i zlecenie przedstawienia dowodów wobec zasady skargowości}

Prima facie wydaje się, że sytuacja, w której sąd zamiast zrealizować obowiązek rozpoznania sprawy, zwraca ją, nakazując organowi postępowania przygotowawczemu uzupełnienie określonych braków i tym samym uchylając stan zawisłości sprawy, jest nie do pogodzenia z zasadą skargowości, zakazującą sądowi samodzielnego inicjowania rozpoznania sprawy. Podobnie jeśli chodzi o sytuację, w której już takiego kroku) jest oczywiście sprzeczne z zasadą skargowości, nie można przejść do porządku dziennego, mając na względzie, iż w doktrynie wyrażano niekiedy stanowisko, jakoby instrumenty te wcale nie stanowiły odstępstwa od omawianej zasady. Gdyby przyjąć, że skoro skargowość obliguje sąd do rozpoznania sprawy, to organ ten musi dysponować środkami, by uzyskać kompletny materiał dowodowy, wówczas można by nawet forsować pogląd, że możliwość zwrotu postępowania do uzupełnienia braków zapewnia wręcz bardziej efektywną realizację omawianej zasady. Według takiej, nieco przewrotnej interpretacji zwrot sprawy i zakreślenie terminu do przedstawienia dowodów byłyby w pełni zgodne, a nawet stanowiłyby przejaw zasady skargowości. Takie rozumowanie obarczone jest błędnym pojmowaniem istoty zasady skargowości, która tkwi nie tyle w obowiązku rozpoznania sprawy, bo ten wynika z zasady legalizmu, lecz w zakazie wykraczania poza granice przedmiotowe i podmiotowe skargi. W tym sensie zwrócenie uwagi jednej ze stron na braki i skłonienie jej od ich uzupełnienia, co przecież potencjalnie może skutkować poszerzeniem granic skargi, powinno być uznane za, usprawiedliwione bądź też nie, ale z pewnością odstępstwo od zasady skargowej.

W doktrynie wyrażono pogląd, że „związanie oskarżyciela decyzją sądu ma charakter ograniczony, ponieważ po zwrocie sprawy oskarżyciel publiczny znów staje się gospodarzem postępowania, a więc nie dochodzi do naruszenia istoty zasady skargowo- 
ści” ${ }^{40}$. Wydaje się jednak, że rzecz nie w tym, kto jest gospodarzem postępowania po zwrocie, lecz przede wszystkim w tym, z czyjej inicjatywy następuje zwrot. W tym przypadku dzieje się to $z$ inicjatywy sądu, a nie strony, to zaś jest nie do pogodzenia z istotą zasady skargowości. W opinii niektórych przedstawicieli doktryny „sąd, cofając proces karny, nie narzuca treści skargi, wskazuje jedynie czynności i okoliczności, które powinny być przeprowadzone i wyjaśnione. Decyzja dotycząca zarówno treści skargi, jak i samego faktu jej wniesienia pozostawiona jest wyłącznie oskarży- sprzeczny z koncepcją czystej skargowości ${ }^{42}$. Podsumowując, instytucja zwrotu skargi z pewnością stanowi wyłom od wynikającej z zasady skargowości obligującej mocy aktu oskarżenia i pozostałych rodzajów skarg. Dodatkowo należy zauważyć, że stanowi odstępstwo od tej zasady również w tym zakresie, w jakim skarga ma pełnić rolę obowiązku procesowego; wszak na podstawie art. 344a k.p.k. sąd nie podejmuje działań, do których na skutek wniesienia skargi jest zobligowany. Także w przypadku art. 396a k.p.k., który zastąpił art. 397 k.p.k., ograniczenie zasady skargowości jest

\section{Instytucja zwrotu skargi z pewnością stanowi wyłom od wynikającej z zasady skargowości obligującej mocy aktu oskarżenia i pozostałych rodzajów skarg.}

cielowi publicznemu. [...] Sąd nie ma prawnych możliwości zmuszenia go do wniesienia skargi”, co miałoby świadczyć o tym, że konstrukcja przekazania sprawy do uzupełnienia braków w pełni respektuje zasadę skargowości ${ }^{41}$. Pogląd ten można by zaaprobować jedynie wówczas, gdyby rozumieć zasadę skargowości na sposób wąski, odnosząc ją jedynie do czynności wniesienia aktu oskarżenia i tym samym wszczęcia postępowania sądowego. Jednak, jak już podkreślono, bardziej trafne wydaje się przyjęcie szerokiego ujęcia skargowości, zarówno ze względu na brzmienie przepisu art. $14 \$ 1$ k.p.k. in fine, jak i fakt, że działanie przez sąd na wniosek zainteresowanych podmiotów pełni funkcję gwarancyjną na całym etapie procesu, a nie jedynie w momencie wszczęcia postepowania sądowego.

Podzielić należy zapatrywanie Romualda Kmiecika, skądinąd przeciwnika likwidacji art. 345 k.p.k., który zwrot do uzupełnienia braków uważa za oczywiście

40 J. Tylman (w:) T. Grzegorczyk, J. Tylman, Polskie postępowanie..., dz. cyt., s. 751.

41 R. Olszewski, Ujawnianie przez sąd i usuwanie istotnych braków dochodzenia lub śledztwa w polskim procesie karnym, Łódź 2007, s. 64. ewidentne, choć $z$ uwagi na etap postępowania częściej wskazuje się tu na wyjątek od zasady kontradyktoryjności ${ }^{43}$, bowiem żądanie przedstawienia dowodów następuje już w momencie, kiedy toczy się merytoryczny spór obu stron przed sądem. Jednak mając na uwadze obligującą funkcję skargi, można zasadnie twierdzić, że zakreślenie oskarżycielowi terminu do przedstawienia dodatkowych dowodów stanowi odstępstwo również od zasady skargowości. Nie ma przesady w twierdzeniu, iż sąd, zlecając dokonanie czynności przez oskarżyciela i tym samym inicjując aktywność dowodową jednej ze stron, zastępuje organy ścigania ${ }^{44}$.

42 R. Kmiecik, Kontrowersyjne unormowania $w$ znowelizowanym kodeksie postępowania karnego, „Prokuratura i Prawo” 2015, nr 1-2, s. 21.

43 R.A. Stefański, Rzetelne postępowanie przed sądem pierwszej instancji (w:) J. Skorupka, W. Jasiński (red.) Rzetelny proces karny. Materiały konferencji naukowej. Trzebieszowice, 17-19 września 2009 r., Warszawa 2010, s. 67. Tak też J. Skorupka, Inkwizycyjna rola sądu w postępowaniu głów nym (w:) T. Grzegorczyk, J. Izydorczyk, R. Olszewski (red.), $Z$ problematyki funkcji procesu karnego, Warszawa 2013 s. 537; P. Wiliński, Materialny ciężar..., dz. cyt., s. 1851-1852. 44 Podobnie S. Cora, Zwrot sprawy..., dz. cyt., s. 28-29. 


\section{Kolizja zasady skargowości z innymi zasadami procesowymi}

Dotychczas poczynione rozważania, prowadzące do wniosku, że opisywane instytucje stanowią odstępstwa od zasady skargowości nie powinny być automatycznie odczytywane jako krytyka i zarazem postulat ich wyeliminowania z procesu karnego. Samo tylko stwierdzenie, że dana regulacja nie przyczynia się do realizacji określonej zasady czy wręcz taką realizację wyklucza, nie przesądza jeszcze kwestii zasadności jej występowania. Wprawdzie u podstaw naczelnych zasad procesowych leżą zawsze motywacje aksjologiczne, jednak, jak już wskazano, naczelne zasady procesowe (a przynajmniej ich znaczna część) z definicji mają charakter optymalizacyjny.

$\mathrm{Na}$ tle konfliktu pomiędzy zasadą skargowości a przywróconymi do procedury karnej regulacjami zarysowuje się typowa kolizja naczelnych zasad procesowych. Z jednej strony realizacji domaga się zasada skargowa, z drugiej zaś należy dołożyć starań, aby urzeczywistnić zasadę ekonomii procesowej, koncentracji materiału dowodowego i prawdy materialnej, którym w pewnych okolicznościach lepiej może służyć działanie z urzędu i inkwizycyjność. Myliłby się ten, kto by sądził, że w sytuacji kolizji fundamentalnej dla procesu zasady skargowości z bardziej prakseologicznie zorientowaną zasadą ekonomii procesowej i koncentracji materiału dowodowego ta druga zawsze będzie musiała ustąpić pierwszej jako ważniejszej, bardziej doniosłej, silniej zakotwiczonej aksjologicznie itd. Trafnie wskazuje się bowiem, że naczelnych zasad procesowych nigdy nie można zhierarchizować a priori, bez odniesienia do konkretnego rozwiązania procesowego. Dopiero w przypadku konkretnej kolizji zasad możliwe jest ich wyważenie i wybór preferowanej ${ }^{45}$.

Jednocześnie za każdorazową rezygnacją z urzeczywistnienia danej zasady powinny stać określone argumenty. R. Alexy wskazuje, że w przypadku kolizji

45 Szerzej na ten temat zob. M. Dąbrowska-Kardas, Kara jako konflikt dóbr i kolizja norm w świetle koncepcji Roberta Alexy'ego konfliktu regut $i$ kolizji zasad. Rozważania na tle konstytucyjnych norm stanowienia i stosowania prawa, „Przegląd Sejmowy” 1996, nr 4; zob. również J. Skorupka, O sprawiedliwości procesu karnego, Warszawa 2013, s. 260 in. zasad obowiązuje wymóg proporcjonalności oznaczający, że realizacja jednej zasady powinna w możliwie jak najmniejszym stopniu powodować uszczerbek $\mathrm{w}$ realizacji drugiej ${ }^{46}$. Pytanie więc, czy przedstawione odstępstwa od zasady skargowości (wskazanie przez sąd braków postępowania, okoliczności, które należy wyjaśnić, lub czynności, które należy przeprowadzić, albo też zakreślenie oskarżycielowi terminu do uzupełnienia braków) zostały zaprojektowane w taki sposób, by zasady skargowości nie ograniczać ponad potrzebną miarę. Czy argumenty przemawiające za tym ograniczeniem są wystarczające, by przełamać zasadę, w myśl której ściganie i oskarżanie stanowić ma domenę jednej ze stron, a nie sądu?

Zaletą obu odstępstw od zasady skargowości jest to, że zapobiegają przewlekłości procesu. Zbieranie i utrwalanie dowodów w sposób najbardziej efektywny następuje w toku postępowania przygotowawczego. Dodatkowo zwrot do uzupełnienia braków posiada ważną zaletę dla oskarżonego, stanowi bowiem możliwość uniknięcia nieuzasadnionej stygmatyzacji związanej ze stanięciem pod zarzutami na jawnej dla społeczeństwa rozprawie sądowej, w czym dostrzec można istotny mechanizm gwarancyjny. Zwrot sprawy prokuratorowi odgrywa ważną rolę w fazie tzw. oddania pod sąd, o której Stanisław Śliwiński pisał: „istotę bowiem tej instytucji stanowi przede wszystkim to, że ma ona zapewnić obywatelowi gwarancję procesową, że nie będzie on ofiarą bezpodstawnych i nieuzasadnionych oskarżeń pozbawionych zwłaszcza dostatecznej podstawy faktycznej, że będzie chroniony przed hańbą niesłusznego zasiadania na ławie oskarżonych na jawnej (w zasadzie) rozprawie. [...] [Oddanie pod sąd] chronić ma powagę państwa, a również personel sądowy i prokuratorski oraz strony przed niepotrzebną pracą oraz ponoszeniem kosztów, które łączą się z przeprowadzeniem rozprawy głównej" ${ }^{47}$. Instytucja zwrotu do uzupełnienia braków zawiera w sobie element kontroli dojrzałości sensu largo oskarżenia do możliwości wyznaczenia rozprawy głównej lub posiedzenia celem meryto-

46 M. Dąbrowska-Kardas, Kara jako konflikt dóbr..., dz. cyt., s. 24 .

47 S. Śliwiński, Oddanie pod sąd w procesowym prawie karnym, Warszawa 1955, s. 131. 
rycznego rozstrzygnięcia w przedmiocie procesu ${ }^{48}$. Argumentację tę osłabia nieco fakt, że w znacznej części rolę taką i tak odgrywa już inny środek zaradczy w postaci możliwości zwrotu z uwagi na oczywisty brak faktycznych podstaw oskarżenia, uregulowany w art. $339 \$ 3$ pkt 2 k.p.k. uzasadniona silnymi argumentami, także o charakterze gwarancyjnym. Nie można już jednak powiedzieć tego samego o czysto „dowodowym” zwrocie do uzupełnienia braków i w tym zakresie należy postulować pozbawienie sądu takiej możliwości, tym bardziej że występuje w k.p.k. swoisty wentyl bez-

\section{Można rozważać częściowe utrzymanie} instytucji zwrotu sprawy $z$ art. $344 a$

\section{k.p.k. w zakresie obejmującym wyłącznie uchybienia natury proceduralnej.}

Analizując doktrynalny spór dotyczący słuszności omawianych rozwiązań procesowych, można odnieść wrażenie, że niektórym komentatorom umyka istotna różnica pomiędzy dwoma rodzajami braków, które sanować można w drodze art. 345 , a obecnie art. $344 \mathrm{a}$ k.p.k. O ile potrzeba naprawy uchybień proceduralnych, zwłaszcza tych, które ograniczają prawo oskarżonego do obrony, zasługuje na aprobatę i w żaden sposób nie stawia bezstronności sądu pod znakiem zapytania, o tyle czymś zupełnie odmiennym jest sytuacja, gdy sąd przychodzi organom ścigania w sukurs, pośrednio zbierając i utrwalając dowody. Ta druga sytuacja w świetle poczynionych rozważań jest nieakceptowalna, natomiast można rozważać częściowe utrzymanie instytucji zwrotu sprawy z art. 344a k.p.k. w zakresie obejmującym wyłącznie uchybienia natury proceduralnej. Argumentację tę wspiera m.in. fakt, że do zwrotu dochodzi jeszcze w fazie tzw. oddania pod sąd przez sąd, kiedy to oskarżony nie został postawiony pod pręgierzem publicznego oskarżenia. Wydaje się, że w tak okrojonej postaci instytucja ta stanowiłaby racjonalne odstępstwo od zasady skargowości, bowiem po pierwsze, nie stanowiłaby tak daleko idącego wyjątku od niej, a po drugie, byłaby

48 D. Osowska, Sądowa kontrola oskarżenia w polskim procesie karnym, Warszawa 1977, s. 6; zob. też T. Razowski, Formalna i merytoryczna..., dz. cyt., s. 187. pieczeństwa w postaci umorzenia $\mathrm{z}$ uwagi na oczywisty brak faktycznych podstaw oskarżenia. Jeśli już koniecznie obstawać przy utrzymaniu obecnego kształtu zwrotu sprawy do uzupełnienia braków, wartą przemyślenia propozycję formułuje Jarosław Zagrodnik, który postuluje, aby w takiej sytuacji wyłączać sędziego od dalszego udziału w sprawie w celu uwolnienia go od psychologicznego związania własnym osądem na dalszym etapie postępowania ${ }^{49}$. Rozważenie tego postulatu oczywiście przekraczałoby ramy tematyczne niniejszego opracowania; warto jedynie zauważyć, że likwidacja „dowodowego” charakteru zwrotu, o którym mowa w art. 344a k.p.k., i ograniczenie go wyłącznie do możliwości usunięcia uchybień o charakterze proceduralnym oszczędziłyby konieczności wprowadzenia kolejnej przyczyny wyłączenia sędziego.

Brak natomiast przesłanek przemawiających za utrzymaniem w jakimkolwiek zakresie art. 396a k.p.k. Nawet R. Kmiecik, broniąc uchylonego art. 345 k.p.k., uznawał za uzasadnioną likwidację art. 397 k.p.k., będącego w jego ocenie legislacyjnie nieudaną namiastką zwrotu sprawy z rozprawy głównej do postępowania przygotowawczego, usuniętego

49 Zob. J. Zagrodnik, Model interakcji postępowania przygotowawczego oraz postępowania głównego w procesie karnym, Warszawa 2013, s. 410-411. 
z k.p.k. w 2003 r. ${ }^{50}$ Sąd zlecający oskarżycielowi dokonanie określonych czynności dowodowych rażąco przekracza granice pełnionej funkcji rozstrzygania, co może być szczególnie wyraźne w sytuacji, gdy zlecone czynności mają decydujący wpływ na skazanie. W przypadku art. 396a k.p.k. ceną potencjalnego tylko
Na zakończenie warto raz jeszcze przypomnieć, że zasada skargowości, nadwątlona wskutek wprowadzenia art. 344a i art. 396a k.p.k., pełni istotną rolę gwarancyjną dla oskarżonego, dając mu zapewnienie, że sąd nie będzie przedsiębrał kroków przeciw niemu i że nie będzie wspomagał strony przeciwnej

\section{W przypadku art. 396a k.p.k. ceną potencjalnego tylko przyspieszenia rozstrzygnięcia} sprawy jest pozbawienie sądu autorytetu związanego $\mathrm{z}$ jego bezstronnością.

przyspieszenia rozstrzygnięcia sprawy jest pozbawienie sądu autorytetu związanego $\mathrm{z}$ jego bezstronnością. Należałoby postulować zatem zerwanie z tym przejawem odpowiedzialności sądu za wynik sprawy, tym bardziej że - jak się trafnie wskazuje - cele instytucji mogą być $\mathrm{z}$ powodzeniem realizowane $\mathrm{w}$ ramach przerwy lub odroczenia rozprawy ${ }^{51}$. Na uwagę zasługuje propozycja Jerzego Skorupki, który dopuszcza możliwość zwrócenia uwagi na braki w przedstawionym materiale dowodowym przez wskazanie nieudowodnionych okoliczności, lecz nie dowodów, które należy przeprowadzićs2.

50 R. Kmiecik, Kontrowersyjne unormowania..., dz. cyt., s. 21; zob. także K. Kurowski, Usunięcie istotnych braków postępowania przygotowawczego przez sąd pierwszej instancji w trybie art. $344 a$ i art. 196 a k.p.k. (w:) D. Kala, I. Zgoliński (red.), Postepowanie przed sadem I instancji $w$ znowelizowanym procesie karnym, Warszawa 2018, s. 137-140.

51 R. Olszewski, Uzupetnianie postępowania przygotowawczego na podstawie orzeczenia sądu - powrót do znanych instytucji i nowe możliwości procesowe (w:) T. Grzegorczyk, R. Olszewski (red.), Verba volant, scripta manent. Proces karny, prawo karne skarbowe i prawo wykroczeń po zmianach z lat 2015-2016. Księga pamiątkowa poświęcona Profesor Monice Zbrojewskiej, Warszawa 2017, s. 295.

52 J. Skorupka, Model postępowania przygotowawczego i sądowego, „Biuletyn Komisji Kodyfikacyjnej Prawa Karnego” 2010, nr 1, s. 35-36. w procesie. Zwrot sprawy do postępowania przygotowawczego z uwagi na braki dowodowe w sposób nieuchronny tworzy wrażenie, że sąd w jakimś stopniu partycypuje w ściganiu i oskarżaniu. Nawet jeśli za taką decyzją stać będzie chęć dokładnego, maksymalnie wnikliwego zbadania sprawy w celu sprawiedliwego rozstrzygnięcia, to jednak sytuacja taka jawi się jako wysoce niepożądana. Szybkie i efektywne procedowanie nie może odbywać się kosztem bezstronności sądu, choćby nawet miało ono prowadzić do naruszenia zewnętrznego wizerunku sądu, a nie jego rzeczywistego nastawienia. W przypadku tej kolizji zasad procesowych pierwszeństwo należy zatem przyznać zasadzie skargowości jako istotnej gwarancji bezstronności sądu i tym samym niezbędnego elementu rzetelnego procesu karnego.

\section{Bibliografia}

Alexy R., Teoria praw podstawowych, tłum. B. Kwiatkowska, J. Zajadło, Warszawa 2010.

Araszkiewicz M., Gizbert-Studnicki T., Teoria praw podstawowych Roberta Alexy'ego, „Przegląd Sejmowy” 2011, nr 3.

Bafia J., Zwrot sprawy przez sąd do uzupetnienia śledztwa lub dochodzenia, Warszawa 1961.

Bieńkowska B.T., Wybrane aspekty wzajemnej relacji zasad skargowości i kontradyktoryjności oraz ich wpływu na określenie formy procesu i kształtu sporu stron przed sądem, „Przegląd Sądowy" 1997, nr 6. 
Bogucki O., Zieliński M., Zasady prawa z perspektywy ogólnej teorii prawa (w:) P. Wiliński (red.) System Prawa Karnego Procesowego, t. 3: Zasady procesu karnego, cz. 1, Warszawa 2014.

Cieślak M., Polska procedura karna. Podstawowe założenia teoretyczne, Warszawa 1974.

Cora S., Zwrot sprawy do uzupetnienia braków postępowania przygotowawczego w polskim procesie karnym, Warszawa 1987

Dąbrowska-Kardas M., Kara jako konflikt dóbr i kolizja norm $w$ świetle koncepcji Roberta Alexy'ego konfliktu reguł $i$ kolizji zasad. Rozważania na tle konstytucyjnych norm stanowienia i stosowania prawa, „Przegląd Sejmowy” 1996, nr 4.

Dudka K., Paluszkiewicz H., Postępowanie karne, Warszawa 2016.

Gizbert-Studnicki T., Zasady i reguły prawne, „Państwo i Prawo” 1988, z. 3.

Glaser S., Wstęp do nauki procesu karnego, Warszawa 1928.

Grzegorczyk T., Tylman J., Polskie postępowanie karne, Warszawa 2014.

Hofmański P., Sadzik E., Zgryzek K., Kodeks postępowania karnego. Komentarz do artykułów 297-467, t. 2, Warszawa 2011

Kmiecik R., Kontrowersyjne unormowania $w$ znowelizowanym kodeksie postępowania karnego, „Prokuratura i Prawo 2015, nr 1-2.

Kmiecik R., Oskarżyciel posiłkowy w procesie karnym, Warszawa 1977.

Kmiecik R., Skrętowicz E., Proces karny. Częséc ogólna, Warszawa 2009.

Korycka M., Teoria zasad prawnych Roberta Alexy'ego, „Archiwum Filozofii Prawa i Filozofii Społecznej” 2010, nr 1.

Kruk E., Zasada skargowości w polskim procesie karnym, „Studia Iurudica Lublinensia" 2016, t. 25.Kulesza C., Zasada skargowości (w:) P. Wiliński (red.), System Prawa Karnego Procesowego, t. 3: Zasady procesu karnego, cz. 1, Warszawa 2014.

Kurowski, Usunięcie istotnych braków postępowania przygotowawczego przez sąd pierwszej instancji w trybie art. 344 a i art. 196 a k.p.k. (w:) D. Kala, I. Zgoliński (red.), Postępowanie przed sadem I instancji $w$ znowelizowanym procesie karnym, Warszawa 2018.

Latos M., Istotne braki postępowania przygotowawczego w judykaturze, „Prokuratura i Prawo” 2010, nr 6.

Lewczyk P., Procesowa kontrola postępowania przygotowawczego, „Prokuratura i Prawo” 2006, nr 9.

Murzynowski A., Istota i zasady procesu karnego, Warszawa 1984. Murzynowski A., Znaczenie zasad skargowości i kontradyktoryjności $w$ działalności sądów w świetle przepisów nowego kodeksu postępowania karnego (w:) T. Nowak (red.), Nowe prawo karne procesowe. Zagadnienia wybrane. Ksiega ku czci Profesora Wiesława Daszkiewicza, Poznań 1999.

Olszewski R., Ujawnianie przez sąd $i$ usuwanie istotnych braków dochodzenia lub śledztwa w polskim procesie karnym, Łódź 2007.

Olszewski R., Uzupetnianie postępowania przygotowawczego na podstawie orzeczenia sądu - powrót do znanych instytucji i nowe możliwości procesowe (w:) T. Grzegorczyk, R. Olszewski (red.), Verba volant, scripta manent. Proces karny, prawo karne skarbowe i prawo wykroczeń po zmianach z lat 2015-2016. Księga pamiątkowa poświęcona Profesor Monice Zbrojewskiej, Warszawa 2017.

Osowska D., Sądowa kontrola oskarżenia w polskim procesie karnym, Warszawa 1977.

Razowski T., Formalna i merytoryczna kontrola oskarżenia w polskim procesie karnym, Kraków 2005.

Skorupka J., Inkwizycyjna rola sądu w postępowaniu głównym (w:) T. Grzegorczyk, J. Izydorczyk, R. Olszewski (red.), Z problematyki funkcji procesu karnego, Warszawa 2013.

Skorupka J., Model postępowania przygotowawczego i sadowego, „Biuletyn Komisji Kodyfikacyjnej Prawa Karnego” 2010, nr 1. Skorupka J., O sprawiedliwości procesu karnego, Warszawa 2013. Stachowiak S., Czynności sądu w fazie poprzedzającej rozprawe główną w ujęciu nowego kodeksu postępowania karnego (w:) Nowa kodyfikacja karna. Kodeks postępowania karnego. Krótkie komentarze, z. 3, Warszawa 1997.

Stachowiak S., Decyzje procesowe podejmowane po uzupetnieniu śledztwa lub dochodzenia w polskim postępowaniu karnym (w:) J. Skorupka (red.), Rzetelny proces karny. Księga jubileuszowa Profesor Zofii Świdy, Warszawa 2009.

Stachowiak S., Funkcje zasady skargowości w polskim procesie karnym, Poznań 1975.

Stachowiak S., Uzupetnienie postępowania przygotowawczego przez prokuratora (art. 397 \$ 1 k.p.k.), „Prokuratura i Prawo” 2003, nr 10.

Stefański R.A., Czynności dowodowe prokuratora zlecone przez sąd, „Prokuratura i Prawo” 2003, nr 5.

Stefański R.A., Rzetelne postępowanie przed sądem pierwszej instancji (w:) J. Skorupka, W. Jasiński (red.), Rzetelny proces karny. Materiały konferencji naukowej. Trzebieszowice, 17-19 września 2009 r., Warszawa 2010.

Śliwiński S., Oddanie pod sąd w procesowym prawie karnym, Warszawa 1955.

Śliwiński S., Polski proces karny przed sądem powszechnym. Zasady ogólne, Warszawa 1948. 
Waltoś S., Hofmański P., Proces karny. Zarys systemu, Warszawa 2016.

Wiliński P., Materialny ciężar dowodu winy oskarżonego - przyczynek do rozważań (w:) P. Kardas, T. Sroka, W. Wróbel (red.), Państwo prawa i prawo karne. Ksiega Jubileuszowa Profesora Andrzeja Zolla, t. 2, Warszawa 2012.

Zagrodnik J., Model interakcji postępowania przygotowawczego oraz postępowania głównego w procesie karnym, Warszawa 2013.

\section{Akty prawne}

Ustawa z dnia 27 września 2013 r. o zmianie ustawy - Kodeks postępowania karnego oraz niektórych innych ustaw, Dz.U. 2013, poz. 1247 ze zm.

Ustawa z dnia 20 lutego 2015 r. o zmianie ustawy - Kodeks karny oraz niektórych innych ustaw, Dz.U. 2015, poz. 396.

Ustawa z dnia 11 marca 2016 r. o zmianie ustawy - Kodeks postępowania karnego oraz niektórych innych ustaw, Dz.U. 2016, poz. 437. 